\title{
Study on the Effect of Tennis on the Physical Health of Middle-Aged and Old People in Nanchang City of Jiangxi Province in China
}

\author{
Jianxin $\mathrm{Gao}^{1 *}$ \\ ${ }^{1}$ Department of sports, Jiangxi Teachers College, Yingtan, Jiangxi, 335000, China \\ *Corresponding author's e-mail: gaojianxin1985@126.com .Tel:+(86)18070187538
}

\begin{abstract}
By testing many physiological indexes of middle-aged and old people in Nanchang city, Jiangxi province, this paper studies the fitness effect of tennis on middle-aged and old people, explores the unique fitness effect of tennis on middle-aged and old people, and objectively evaluates it. Therefore, it is of great significance for the elderly to take part in tennis regularly in order to reduce work pressure, avoid the appearance of sub-health, to be happy physically and mentally, and to strengthen their health. The experiment was completed in September 2019 at the national fitness centre of Nanchang city Jiangxi province in China. Before and after the experiment, a total of 127 middle-aged and elderly subjects were measured, including body shape, physical function, physical quality, body composition. The author used SPSS software of sports statistics to make statistics on the test results. after 6 months of tennis training, there were significant changes in middle-aged and old people on body circumference, skin fold thickness, heart rate, blood pressure, vital capacity, main muscle strength, sitting forward bending, standing with closed eyes and one foot, reaction time and Harvard step index. There were also significant differences in subject body weight, BMI, FAT, LBW, protein and inorganic salt in each experiment group. tennis has an important role and value in improving the physical health of middle-aged and elderly people. This article objectively evaluates the fitness effect of tennis so as to provide a more scientific and reasonable theoretical basis for the fitness project of tennis, and further explore its unique fitness efficacy, so as to play a greater role in improving the health level of the elderly.
\end{abstract}

Keywords: Tennis sport; Elderly people; Physical health; Experimental study

\section{Introduction}

With the rapid economic development and social progress in China, the quality of life of the people is constantly improving, and the aging degree of the population is also getting higher and higher. Population aging has become a major social problem facing the whole world, and has begun to attract the universal attention of the international community. Relevant scholars in the study pointed out that the population over 60 accounted for $10 \%$ of the total population or over 65 accounted for $7 \%$ of the total population, which can be called "aging society" or "aging society". The data show that by the end of 2017, the elderly population aged 60 and over in China had exceeded 250 million, accounting for $17.9 \%$ of the total population; the elderly population aged 65 and over had exceeded 150 million, accounting for $10.8 \%$ of the total population (data from China Aging Development Report 2018). Seriously, the number of elderly people in China is increasing at a rate of $3.2 \%$. Relevant experts preliminarily predict that by 2050 , the number of elderly people in China will reach 480 million, accounting for about two fifths of the Asian elderly population and one quarter of the global elderly population. In addition, due to the increasing pressure of people's life and the accelerated pace of social life, a considerable proportion of people in China are in sub-health state. According to the latest statistics of the World Health Organization, the population in sub-health state accounts for about $70 \%$ of the total population in China, and health problems are worrying. With the development of economy, the development of science and technology, and the continuous improvement of medical facilities, the main diseases and death causes of human began to shift from major diseases to the current ones caused by inadequate exercise and excessive nutrition, commonly known as "civilized disease". Tennis is a sport that integrates fitness, entertainment and confrontation. It has the characteristics of universality, interestingness, playfulness, comprehensive efficiency, adjustability, etc. It is easy to popularize and carry out. It also has the sport value of fitness and health. Meanwhile, it studies the development status of tennis among middle-aged and old people in Nanchang city. The article will further explore and analyze the characteristics and value of tennis. This paper analyses and studies the influence of tennis on the physical and mental health of middle-aged and old people in Nanchang by experimental method. On the basis of relevant experimental research, and through the analysis of 
the measured data before and after the experiment, it further explores the positive and unique effect of tennis on improving the physiological function of middle-aged and old people and improving their mental health, to provide a scientific theoretical basis for the further promotion of tennis.

\section{Material and Methods}

\subsection{Study population}

By consulting a large number of papers on the definition of the age of middle-aged and elderly people, and according to the actual needs of this study, this study divides the 50-65 age groups into the middle-aged group, and divides the 65-years-old age group into the elderly group. The basic situation of middle-aged and elderly subjects in Nanchang city in China is shown in (Table 1).

Table 1. The basic situation of middle-aged and elderly subjects in Nanchang city $\quad(\bar{x} \pm s, n=127)$

\begin{tabular}{ccccc}
\hline & $\begin{array}{c}\text { Men's } \\
\text { middle age } \\
\text { group }\end{array}$ & $\begin{array}{c}\text { Older male } \\
\text { group }\end{array}$ & $\begin{array}{c}\text { Women's } \\
\text { middle age } \\
\text { group }\end{array}$ & $\begin{array}{c}\text { Female } \\
\text { elderly } \\
\text { group }\end{array}$ \\
\hline $\begin{array}{c}\text { Number } \\
\text { of } \\
\text { subjects } \\
\begin{array}{c}\text { Average } \\
\text { age }\end{array}\end{array}$ & 43 & 25 & 37 & 22 \\
\hline
\end{tabular}

Note: The decrease of the number of subjects in each group after the experiment is due to the loss of subjective and objective factors of the subjects themselves.

\subsection{Experimental arrangement}

All the subjects were divided into three groups and trained in batches. Each group was trained in basic tennis

Table 2. The influence of tennis on the body shape of middle-aged and old people in Nanchang city

\begin{tabular}{|c|c|c|c|c|c|c|c|c|}
\hline & \multicolumn{2}{|c|}{$\begin{array}{l}\text { Men's middle age group } \\
\qquad(\bar{x} \pm s, n=43)\end{array}$} & \multicolumn{2}{|c|}{$\begin{array}{l}\text { Older male group } \\
\qquad(\bar{x} \pm \mathbf{s}, \mathbf{n}=25)\end{array}$} & \multicolumn{2}{|c|}{$\begin{array}{c}\text { Women's middle age } \\
\text { group } \\
(\bar{x} \pm \mathbf{s}, \mathbf{n}=37) \\
\end{array}$} & \multicolumn{2}{|c|}{$\begin{array}{l}\text { Female elderly group } \\
\qquad(\bar{x} \pm \mathbf{s}, \mathbf{n}=22)\end{array}$} \\
\hline & $\begin{array}{c}\text { Pre- } \\
\text { experiment }\end{array}$ & $\begin{array}{c}\text { After the } \\
\text { experiment }\end{array}$ & $\begin{array}{c}\text { Pre- } \\
\text { experiment }\end{array}$ & $\begin{array}{c}\text { After the } \\
\text { experiment }\end{array}$ & $\begin{array}{c}\text { Pre- } \\
\text { experiment }\end{array}$ & $\begin{array}{c}\text { After the } \\
\text { experiment }\end{array}$ & $\begin{array}{c}\text { Pre- } \\
\text { experiment }\end{array}$ & $\begin{array}{c}\text { After the } \\
\text { experiment }\end{array}$ \\
\hline Forearm & $26.04 \pm 0.48$ & $25.08 \pm 0.67 *$ & $25.18 \pm 0.61$ & $24.16 \pm 0.58 *$ & $24.96 \pm 2.57$ & $23.57 \pm 2.53^{*}$ & $25.02 \pm 2.61$ & $24.56 \pm 2.68^{*}$ \\
\hline Chest & $92.30 \pm 6.49$ & $91.73 \pm 6.40$ & $90.95 \pm 6.67$ & $90.25 \pm 6.72$ & $86.83 \pm 6.41$ & $86.21 \pm 6.42$ & $87.35 \pm 6.65$ & $87.07 \pm 6.53$ \\
\hline Waist & $84.50 \pm 8.52$ & $\begin{array}{c}80.09 \pm 8.32 \\
* *\end{array}$ & $84.55 \pm 9.36$ & $\begin{array}{c}79.69 \pm 9.77 \\
* *\end{array}$ & $80.37 \pm 8.95$ & $\begin{array}{c}75.69 \pm 8.72 \\
* *\end{array}$ & $83.05 \pm 8.63$ & $\begin{array}{c}78.24 \pm 8.84 \\
* *\end{array}$ \\
\hline Hipline & $92.47 \pm 5.45$ & $90.19 \pm 4.44 *$ & $92.30 \pm 6.17$ & $89.43 \pm 6.65^{*}$ & $92.86 \pm 5.95$ & $89.81 \pm 5.45^{*}$ & $93.35 \pm 6.47$ & $90.25 \pm 6.65^{*}$ \\
\hline Thigh & $58.34 \pm 5.74$ & $57.94 \pm 5.25$ & $57.21 \pm 5.32$ & $56.88 \pm 5.40$ & $49.80 \pm 3.54$ & $47.74 \pm 3.82 *$ & $49.37 \pm 3.58$ & $47.21 \pm 3.65^{*}$ \\
\hline Leg & $35.83 \pm 2.57$ & $34.52 \pm 2.28$ & $34.75 \pm 2.99$ & $33.86 \pm 2.53$ & $33.72 \pm 2.95$ & $31.86 \pm 2.57$ & $33.45 \pm 3.08$ & $31.79 \pm 2.91$ \\
\hline
\end{tabular}

Note: * The results showed that there was a significant difference $(\mathrm{P}<0.05)$ between before and after the experiment, $* *$ showed a significant difference $(\mathrm{P}<0.01)$ between before and after the experiment, and there was no significant difference $(\mathrm{P}>0.05)$ between before and without labeling * (The same situation in the note for below tables. ) movements for one month, three times a week and two hours at a time. After the middle-aged and elderly subjects mastered the basic tennis movements, they began to exercise formally. The practice lasted for six months. They guaranteed to exercise more than three times a week for 90 minutes each time. They were prepared and warmed up 15 minutes before the exercise, 60 minutes in the middle of exercise contact, the last 15 minutes to organize activities. Subjects practice relatively fixed time, according to personal conditions in the process of practice gradually increase the difficulty of technical movements, but will not overload training exercises, to follow its natural, comfortable-oriented way. In the experiment, the heart rate intensity of middle-aged and old people participating in physical exercise should be controlled at 130-150 times per minute to ensure the safety of physical exercise.

\section{Results}

Body shape, function, quality and composition can objectively reflect and evaluate the physical health of middle-aged and elderly subjects, but also the basic content of evaluating the effect of physical exercise. The experimental study was conducted to compare the changes of body shape, body function, physical fitness and body composition of 127 middle-aged and elderly people in Nanchang after six months of tennis exercise to explore the effect of tennis on the health of middle-aged and old people.

\subsection{The influence of tennis on the body shape of middle-aged and old people in Nanchang city}




\subsection{The effect of tennis on physical function}

Table 3. The effect of tennis on physical function of middle-aged and old people in Nanchang city

\begin{tabular}{|c|c|c|c|c|c|c|c|c|}
\hline & \multicolumn{2}{|c|}{$\begin{array}{l}\text { Men's middle age group } \\
\qquad(\bar{x} \pm \mathbf{s}, \mathbf{n}=\mathbf{4 3})\end{array}$} & \multicolumn{2}{|c|}{$\begin{array}{l}\text { Older male group } \\
(\bar{x} \pm \mathbf{s}, \mathbf{n}=25)\end{array}$} & \multicolumn{2}{|c|}{$\begin{array}{c}\text { Women's middle age } \\
\text { group } \\
(\bar{x} \pm \mathbf{s}, \mathbf{n}=37) \\
\end{array}$} & \multicolumn{2}{|c|}{$\begin{array}{l}\text { Female elderly group } \\
\qquad(\bar{x} \pm \mathbf{s}, \mathbf{n}=22)\end{array}$} \\
\hline & $\begin{array}{c}\text { Pre- } \\
\text { experimen } \\
t\end{array}$ & $\begin{array}{c}\text { After the } \\
\text { experiment }\end{array}$ & $\begin{array}{c}\text { Pre- } \\
\text { xperiment }\end{array}$ & $\begin{array}{c}\text { After the } \\
\text { experiment }\end{array}$ & $\begin{array}{c}\text { Pre- } \\
\text { xperiment }\end{array}$ & $\begin{array}{c}\text { After the } \\
\text { experimen } \\
t\end{array}$ & $\begin{array}{c}\text { Pre- } \\
\text { experiment }\end{array}$ & $\begin{array}{c}\text { After the } \\
\text { experimen } \\
\text { t }\end{array}$ \\
\hline $\begin{array}{l}\text { Heart rate } \\
\text { (times/m) } \\
\text { Systolic }\end{array}$ & $76.55 \pm 7.92$ & $\begin{array}{l}73.17 \pm 5.60 \\
* *\end{array}$ & $76.93 \pm 8.02$ & $\begin{array}{c}74.95 \pm 7.24 \\
*\end{array}$ & $78.67 \pm 7.40$ & $76.52 \pm 6.06$ & $76.15 \pm 7.76$ & $\begin{array}{c}75.86 \pm 7.00 \\
*\end{array}$ \\
\hline $\begin{array}{l}\text { blood } \\
\text { pressure } \\
(\mathbf{m m})\end{array}$ & $\begin{array}{l}122.73 \pm \\
14.16\end{array}$ & & $\begin{array}{c}128.82 \pm \\
15.39\end{array}$ & & $\begin{array}{c}117.33 \pm \\
14.55\end{array}$ & & & $\begin{array}{c}124.21 \pm \\
13.94 *\end{array}$ \\
\hline $\begin{array}{l}\text { Diastolic } \\
\text { blood } \\
\text { pressure } \\
(\mathrm{mm})\end{array}$ & $80.32 \pm 9.05$ & $\begin{array}{l}77.25 \pm 9.16 \\
*\end{array}$ & $79.51 \pm 9.17$ & $\begin{array}{c}76.83 \pm 8.99 \\
*\end{array}$ & $75.90 \pm 8.72$ & $73.16 \pm 7.73$ & $77.25 \pm 9.24$ & $\begin{array}{c}74.39 \pm 8.46 \\
*\end{array}$ \\
\hline $\begin{array}{c}\text { Vital } \\
\text { capacity (ml) }\end{array}$ & $\begin{array}{c}3143.6 \pm 63 \\
2.98\end{array}$ & $\begin{array}{c}3327.1 \pm 704 \\
.55^{* *}\end{array}$ & $\begin{array}{c}2614.5 \pm 619 \\
.69\end{array}$ & $\begin{array}{c}2836.12 \pm 68 \\
7.45^{* *}\end{array}$ & $\begin{array}{c}2150.5 \pm 493 \\
.46\end{array}$ & $\begin{array}{l}2298.17 \pm 67 \\
5.87 * *\end{array}$ & $\begin{array}{c}1756.3 \pm 446 \\
.21\end{array}$ & $\begin{array}{c}1977.54 \pm 47 \\
8.50^{* *}\end{array}$ \\
\hline
\end{tabular}

\subsection{The effect of tennis on physical quality of middle-aged and old people in Nanchang city}

Table 4. The effect of tennis on physical quality of middle-aged and old people in Nanchang city

\begin{tabular}{|c|c|c|c|c|c|c|c|c|}
\hline & \multicolumn{2}{|c|}{$\begin{array}{l}\text { Men's middle age group } \\
\qquad(\bar{x} \pm s, n=43)\end{array}$} & \multicolumn{2}{|c|}{$\begin{array}{l}\text { Older male group } \\
\qquad(\bar{x} \pm \mathbf{s}, \mathbf{n}=25)\end{array}$} & \multicolumn{2}{|c|}{$\begin{array}{c}\text { Women's middle age } \\
\text { group } \\
(\bar{x} \pm \mathbf{s}, \mathbf{n}=37)\end{array}$} & \multicolumn{2}{|c|}{$\begin{array}{l}\text { Female elderly group } \\
\quad(\bar{x} \pm \mathbf{s}, \mathbf{n}=\mathbf{2 2})\end{array}$} \\
\hline & $\begin{array}{c}\text { Pre- } \\
\text { experimen } \\
t\end{array}$ & $\begin{array}{c}\text { After the } \\
\text { experiment }\end{array}$ & $\begin{array}{c}\text { Pre- } \\
\text { experiment }\end{array}$ & $\begin{array}{c}\text { After the } \\
\text { experiment }\end{array}$ & $\begin{array}{c}\text { Pre- } \\
\text { experiment }\end{array}$ & $\begin{array}{c}\text { After the } \\
\text { experimen } \\
t\end{array}$ & $\begin{array}{c}\text { Pre- } \\
\text { experiment }\end{array}$ & $\begin{array}{c}\text { After the } \\
\text { experimen } \\
t\end{array}$ \\
\hline Grip (kg) & $27.17 \pm 5.90$ & $\begin{array}{l}31.72 \pm 6.33 \\
* *\end{array}$ & $23.65 \pm 7.72$ & $\begin{array}{l}26.53 \pm 4.81 \\
*\end{array}$ & $43.8 \pm 7.25$ & $\begin{array}{l}47.32 \pm 7.73 \\
* *\end{array}$ & $37.57 \pm 7.04$ & $\begin{array}{l}39.25 \pm 6.95 \\
*\end{array}$ \\
\hline $\begin{array}{c}\text { Back } \\
\text { strength (kg) }\end{array}$ & $\begin{array}{l}56.85 \pm 12.4 \\
6\end{array}$ & $\begin{array}{l}60.22 \pm 12.1 \\
6 . * *\end{array}$ & $\begin{array}{l}51.28 \pm 12.3 \\
2\end{array}$ & $\begin{array}{l}53.48 \pm 12.6 \\
6^{*}\end{array}$ & & $\begin{array}{l}86.53 \pm 18.1 \\
3 * *\end{array}$ & $\begin{array}{l}78.43 \pm 16.5 \\
4\end{array}$ & $\begin{array}{l}80.06 \pm 18.4 \\
8^{*}\end{array}$ \\
\hline $\begin{array}{l}\text { Sit-and- } \\
\text { reach }(\mathrm{cm})\end{array}$ & $10.23 \pm 7.36$ & $\begin{array}{l}11.87 \pm 6.00 \\
*\end{array}$ & $10.23 \pm 7.54$ & $10.43 \pm 6.88$ & $5.64 \pm 7.99$ & $6.04 \pm 5.10$ & $3.1 \pm 8.50$ & $3.24 \pm 7.43$ \\
\hline $\begin{array}{l}\text { Stand on one } \\
\text { foot with } \\
\text { closed eyes(s) }\end{array}$ & $\begin{array}{l}15.81 \pm 18.6 \\
4\end{array}$ & $\begin{array}{l}17.21 \pm 18.3 \\
5^{*}\end{array}$ & $9.47 \pm 7.74$ & $10.07 \pm 9.15$ & $\begin{array}{l}17.83 \pm 19.2 \\
6\end{array}$ & $\begin{array}{l}19 . .28 \pm 19.3 \\
8^{*}\end{array}$ & $10.15 \pm 9.78$ & $10.42 \pm 8.87$ \\
\hline $\begin{array}{l}\text { Reaction } \\
\text { time(s) }\end{array}$ & $0.50 \pm 0.102$ & $\begin{array}{l}0.43 \pm 0.092 \\
*\end{array}$ & $0.60 \pm 0.156$ & $0.59 \pm 0.146$ & $0.48 \pm 0.090$ & $\begin{array}{l}0.42 \pm 0.084 \\
*\end{array}$ & $0.56 \pm 0.133$ & $0.55 \pm 0.173$ \\
\hline $\begin{array}{l}\text { Harvard step } \\
\text { index }\end{array}$ & $58.07 \pm 9.56$ & $\begin{array}{l}61.88 \pm 9.13 \\
* *\end{array}$ & $53.02 \pm 8.84$ & $\begin{array}{l}55.47 \pm 8.88 \\
*\end{array}$ & $58.23 \pm 8.99$ & $\begin{array}{l}62.77 \pm 9.37 \\
* *\end{array}$ & $56.41 \pm 8.70$ & $\begin{array}{l}58.69 \pm 9.89 \\
*\end{array}$ \\
\hline
\end{tabular}

\subsection{The effect of tennis on body composition of middle-aged and old people in Nanchang city}

Table 5. The effect of tennis on body composition of middle-aged and old people in Nanchang city

\begin{tabular}{|c|c|c|c|c|c|c|c|c|}
\hline & \multicolumn{2}{|c|}{$\begin{array}{l}\text { Men's middle age group } \\
\qquad(\bar{x} \pm s, n=43)\end{array}$} & \multicolumn{2}{|c|}{$\begin{array}{l}\text { Older male group } \\
(\bar{x} \pm \mathbf{s}, \mathbf{n}=25)\end{array}$} & \multicolumn{2}{|c|}{$\begin{array}{c}\text { Women's middle age } \\
\text { group } \\
(\bar{x} \pm \mathbf{s}, \mathbf{n}=37)\end{array}$} & \multicolumn{2}{|c|}{$\begin{array}{l}\text { Female elderly group } \\
\qquad(\bar{x} \pm \mathbf{s}, \mathbf{n}=22)\end{array}$} \\
\hline & $\begin{array}{c}\text { Pre- } \\
\text { experimen } \\
\mathbf{t} \\
\end{array}$ & $\begin{array}{c}\text { After the } \\
\text { experiment }\end{array}$ & $\begin{array}{c}\text { Pre- } \\
\text { experiment }\end{array}$ & $\begin{array}{l}\text { After the } \\
\text { experiment }\end{array}$ & $\begin{array}{c}\text { Pre- } \\
\text { experiment }\end{array}$ & $\begin{array}{c}\text { After the } \\
\text { experimen } \\
t\end{array}$ & $\begin{array}{c}\text { Pre- } \\
\text { experiment }\end{array}$ & $\begin{array}{c}\text { After the } \\
\text { experimen } \\
t\end{array}$ \\
\hline Weight (kg) & $59.35 \pm 8.03$ & $\begin{array}{l}56.43 \pm 8.94 \\
* *\end{array}$ & $58.65 \pm 8.55$ & $\begin{array}{l}56.88 \pm 8.37 \\
*\end{array}$ & $68.9 \pm 9.43$ & $\begin{array}{l}66.84 \pm 9.20 \\
*\end{array}$ & $66.65 \pm 9.76$ & $\begin{array}{l}64.73 \pm 8.91 \\
*\end{array}$ \\
\hline BMI & $24.08 \pm 2.52$ & $\begin{array}{l}22.99 \pm 3.00 \\
*\end{array}$ & $24.69 \pm 2.84$ & $\begin{array}{l}23.82 \pm 2.74 \\
*\end{array}$ & $24.30 \pm 3.72$ & $\begin{array}{l}23.23 \pm 3.96 \\
*\end{array}$ & $24.37 \pm 3.45$ & $\begin{array}{l}23.58 \pm 4.13 \\
*\end{array}$ \\
\hline FAT (kg) & $18.77 \pm 4.25$ & $\begin{array}{l}16.59 \pm 3.92 \\
*\end{array}$ & $19.79 \pm 4.43$ & $\begin{array}{l}18.30 \pm 4.04 \\
*\end{array}$ & $16.54 \pm 4.36$ & $\begin{array}{l}14.81 \pm 4.37 \\
*\end{array}$ & $17.49 \pm 4.53$ & $\begin{array}{l}15.91 \pm 3.99 \\
*\end{array}$ \\
\hline
\end{tabular}




\begin{tabular}{ccccccccc} 
Protein (kg) & $8.55 \pm 0.80$ & $9.05 \pm 0.84^{*}$ & $8.20 \pm 0.95$ & $8.66 \pm 0.95^{*}$ & $11.45 \pm 1.24$ & $11.98 \pm 1.25$ & $11.03 \pm 1.24$ & $11.39 \pm 1.17$ \\
$\begin{array}{c}\text { Inorganic } \\
\text { salt (kg) }\end{array}$ & $2.88 \pm 0.23$ & $2.90 \pm 0.24$ & $2.78 \pm 0.28$ & $2.82 \pm 0.29$ & $3.63 \pm 0.30$ & $3.65 \pm 0.32$ & $3.54 \pm 0.31$ & $3.56 \pm 0.36$ \\
WHR & $0.86 \pm 0.09$ & $0.84 \pm 0.02 *$ & $0.89 \pm 0.04$ & $0.87 \pm 0.06^{*}$ & $0.89 \pm 0.07$ & $0.88 \pm 0.02$ & $0.91 \pm 0.06$ & $0.89 \pm 0.04 *$ \\
\hline
\end{tabular}

\section{Conclusions}

This paper aims to analyze the effect of tennis on the physical health of middle-aged and old people in Nanchang city of Jiangxi province in China and the conclusions are as follows: Tennis is a sport with the characteristics of fitness, entertainment, participation, aesthetic appreciation and comprehensive effectiveness. By participating in reasonable tennis exercise, the physical fitness of the trainer, such as strength, speed, endurance and so on, can be improved, and at the same time, it plays an important role in improving physical function. After six months of tennis exercise, the experimental study showed that there were significant changes in body shape, body function, physical fitness and body composition of the middle-aged and elderly male and female subjects in Nanchang city, Jiangxi province.

\section{Abbreviations}

BMI, body mass index; LBW, lean body weight; WHR, waist hip ratio; BFA, blood fibrinolytic ability.

\section{References}

[1] Yang Fan, Panyue, Zou Zeyu. Research on the Physical Exercise Status and Influencing Factors of the Elderly in China [J/OL]. China Sports Science and Technology: 1-12 [2019-09-11]. https://doi.org/10.16470/j.csst.2019028.

[2] Zhao Yingjie.The Value of Tennis Training
Monitoring to Amateur Athletes and National Fitness Activities[J].Contemporary Sports Science and Technology, 2019,9(19): 36+39.

[3] Tang Yuan. Practical Research on Traffic Employees Participating in Tennis Fitness [D]. Jiangxi Normal University, 2018.

[4] Guo Hong. Present situation of tennis for the elderly in Wuhan [D]. Central China Normal University, 2017.

[5] Dong Zhizhou. An experimental study on the effect of tennis on the physical health of the elderly in Xuhui District, Shanghai [D]. Shanghai Normal University, 2011.

[6] Zhou Yuli. Current situation and optimization measures of college tennis in Liaocheng under the background of national fitness [J]. Contemporary sports science and technology, 2017,7(19): 71-72.

[7] Fan Yong, Wang Sufang, Sheng Jie, Wang Jun, Xie Shaoyu, Li Kaichun, Ma Ying, Chen Guimei, Yang Linsheng, Tao Fangbiao. Association of waist circumference, waist-hip ratio, waist-height ratio and hypertriglyceridemia among the elderly in Luan City in 2016 [J]. Hygiene Research, 2018, 47 (05): 770-775.

[8] Ling Shuchang. Research on the Construction of Community Public Fitness Service System for the Elderly in Changchun City from the Perspective of "Healthy China 2030" [J] Sports Science and Technology Literature Bulletin, 2019, 27 (08): 52+54. 